\title{
Optimasi Pattern Reconfigurable Antenna Bercelah Melingkar menggunakan Algoritma Genetika
}

\section{DWI ANDI NURMANTRIS ${ }^{1}$, HEROE WIJANTO ${ }^{2}$, BAMBANG SETIA NUGROHO 3}

${ }^{1}$ Fakultas Ilmu Terapan, Telkom University, Indonesia

2,3Fakultas Teknik Elektro, Telkom University, Indonesia

Email : dwiandi@tass.telkomuniversity.ac.id

Received 9 Juli 2019 | Revised 23 September 2019 | Accepted 8 November 2019

\begin{abstract}
ABSTRAK
Penelitian ini bertujuan untuk mendapatkan suatu desain pattern reconfigurable antenna dengan menitikberatkan pada optimasi antena planar berbentuk lingkaran dengan 24 switch berupa shorting pin pada tepi patch dan menambahkan celah melingkar pada patchnya sebagai metode penyepadan impedansi. Algoritma Genetika digunakan sebagai metode optimasi antena sedangkan Finite Element method digunakan sebagai metode komputasi untuk mendapatkan nilai parameter antena ketika proses evaluasi fungsi fitness. Keduanya dikolaborasikan untuk mendapatkan suatu desain antena yang mempunyai kemampuan pattern reconfigurable. Hasilnya diperoleh suatu desain antena pada frekuensi 2,4 Ghz dengan 24 pola pancar yang bisa di switch ke seluruh bidang azzimuth dimana semua pola pancar didesain pada arah elevasi $45^{\circ}$.
\end{abstract}

Kata kunci: optimasi, celah melingkar, algoritma genetika, pattern reconfigurable antenna

\begin{abstract}
This research aims to obtain a reconfigurable antenna pattern design with emphasize on the optimization of a planar circular antenna with 24 switchs on the edge of the patch and add a slit ring in the patch as a impedance matching method. Genetic Algorithm is used as an antenna optimization method while the The Finite Element method is used as a computational method to obtain the antenna parameters value when evaluating the fitness function. Both collaborated to obtain an antenna design that has the pattern reconfigurable ability. The result is 2,4 Ghz antenna design with 24 radiation patterns that can be switched to all azzimuth plane where all are designed in $45^{\circ}$ of elevation plane.
\end{abstract}

Keywords: optimization, slit ring, genetic algorithm, pattern reconfigurable antenna 


\section{PENDAhuluan}

Reconfigurable antenna menjadi salah satu topik hangat yang diteliti oleh para peneliti beberapa tahun terakhir ini. Hal ini didorong oleh kebutuhan komunikasi wireless masa depan yang harus memiliki kemampuan multifungsi dan kemampuan adaptif untuk mendukung sistem komunikasi yang cepat, aman dan tangguh. Kemampuan tersebut sangat dibutuhkan untuk aplikasi modern masa depan yang membutuhkan kecepatan transfer data yang tinggi pada lingkungan kanal wireless yang padat dan tuntutan sistem keamanan data yang tinggi. Untuk menjawab tantangan tersebut, dibutuhkan sistem yang memiliki intelegensi tinggi yang mana tidak hanya didukung oleh teknik pengolahan signal yang canggih tetapi juga harus didukung oleh hardware termasuk antena yang revolusioner (Guo, dkk, 2018).

Pattern Reconfigurable Antenna (PRA) adalah satu di antara jenis reconfigurable antenna yang menarik perhatian dan sangat dibutuhkan terutama pada sistem yang rawan akan multipath interference, misalnya WLAN. Penggunaan PRA pada WLAN bisa meningkatkan Signal to Noise Ratio (SNR) dengan cara mengatur main beam antena ke arah yang diinginkan dan sekaligus menahan beam lainnya ke arah yang lain terutama ke arah sumber interferensi (Tang, dkk, 2018). Selain itu, PRA juga dipersiapkan untuk mengantisipasi kebutuhan sistem komunikasi generasi ke 5 (5G) yang saat ini sedang dikembangkan untuk sistem komunikasi masa depan. Dimana 5G kemungkinan akan bergantung pada cognitive radio, dimana cognitive radio pada dasarnya adalah sistem wireless multifungsi. (Guo, dkk, 2018). Selain kedua aplikasi tersebut, PRA juga sangat potensial digunakan pada aplikasi remote sensing dan Komunikasi Satelit Broadband (Yang \& Zhu, 2018).

PRA pada dasarnya adalah antena yang bisa digunakan untuk aplikasi yang membutuhkan beamsteering/beamswitching. Umumnya, kemampuan beamsteering/beamswitching pada antena bisa didapat dengan teknik phassed array antenna. Dibalik kelebihannya sebagai beamsteering antenna, phased array antenna memiliki kekurangan yaitu ukurannya yang relatif besar karena terdiri dari banyak elemen antena. Selain itu, phassed array antenna juga memiliki kekurangan disisi catuan yang cukup kompleks seperti terlihat pada Gambar 1.

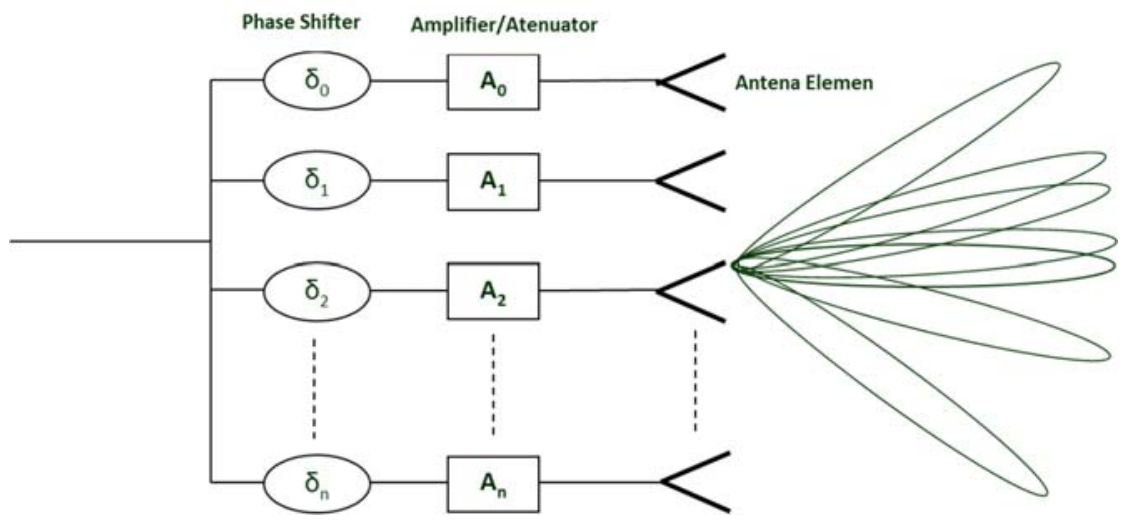

Gambar 1. Pencatuan Phassed Array Antenna

Dibandingkan dengan phassed array antenna, PRA menawarkan keunggulan disisi ukuran dan pencatuan yang lebih sederhana, meskipun kemampuan beamsteering-nya jauh lebih rendah dibandingkan dengan phassed array antenna. Beberapa desain PRA telah dipaparkan oleh beberapa peneliti. Diantaranya (Farran, dkk, 2019) membuat PRA menggunakan dua buah antena yagi uda berbentuk planar yang bisa meng-cover seluruh pancaran bidang 
azimuth. Kemudian (Rezaeieh \& Abbosh, 2019) mendesain PRA menggunakan Huygens Source Theory. Pada penelitian tersebut digunakan dua buah antena dipol yang dikenal dengan dipol elektrik dan dipol magnetik. Dua antena ini dikombinasikan untuk mengatur pola pancar antena. Kemudian juga (Tang, dkk, 2018) membuat PRA menggunakan konsep parasitik antena dengan 3 buah switch dimana masing masing state bisa meng-cover area $120^{\circ}$. Kemudian ada juga (Yang \& Zhu, 2018) membuat PRA menggunakan konsep parasitik antena dengan 6 elemen dimana kemampuan pattern reconfigurable diperoleh dengan menghubungkan elemen parasitik dengan groundplane melalui shorting PIN.

Seluruh PRA yang disampaikan pada penelitian - penelitian tersebut memiliki tingkat kerumitan desain yang cukup tinggi. Hal tersebut dikarenakan teori dan analisis mengenai struktur antena tersebut masih sangat sedikit. Metode Trial Error berbasis Electromagnetic Simulation Tools biasanya digunakan untuk membantu dalam proses desain. Beberapa peneliti biasanya menggabungkan teknik desain ini dengan suatu algoritma optimasi untuk mempermudah dalam proses desain. Salah satu algoritma optimasi yang sering digunakan pada desain antena adalah Algoritma Genetika (AG). Algoritma Genetika dipilih bukan menjadi satu-satunya pilihan tetapi lebih karena sifatnya yang sederhana dan mudah dipahami dengan meniru proses seleksi alam. Beberapa penelitian berhubungan dengan penggunaan algoritma Genetika dalam desain antena di antaranya adalah (Smith \& Baginski, 2019) yang menggunakan Algoritma Genetika dalam mendesain thin wire antenna untuk mendapatkan pola gain yang diinginkan. Kemudian ( $\mathbf{L i}, \mathbf{d k k}, \mathbf{2 0 1 8}$ ) mendesain linear array antenna dengan mengoptimasi jarak antar elemen yang didesain tidak seragam. Algoritma Genetika juga digunakan (Gulati, dkk, 2018) yang mendesain antena planar dimana bagian radiator antena dipartisi menjadi $50 \times 50$ cell kemudian dioptimasi. Kemudian (Zeghdoud, dkk, 2018) mengoptimasi radiator pada antena mekrostrip untuk mendapatkan dualband frequency. Kemudian juga (Zhang, dkk, 2019) mengoptimasi bentuk groundplane (DGS) untuk mendapatkan bandwidth antena yang lebar. Berhubungan dengan penggunaan Algoritma Genetika dalam desain PRA, penulis sebelumnya telah mendesain PRA menggunakan circular patch antenna dengan pencatuan probe koaksial dengan mengoptimasi kombinasi switch di bagian tepi patch dan posisi probe koaksial (Nurmantris, dkk, 2014). Kemudian penulis melakukan penelitian lagi masih menggunakan circular patch antenna dan pencatuan probe koaksial dengan mengoptimasi kombinasi switch di tepi patch dan kombinasi switch yang melingkar di sekitar probe koaksial yang disebut Symmetrical Control Pin (Nurmantris, dkk, 2015). Penggunaan algoritma optimasi dalam mencapai tujuan rekonfigurasi sangatlah membantu dalam segi penggunaan waktu dibandingkan dengan hanya menggunakan metode Trial Error terutama untuk masalah struktur antena yang rumit dan terbatas informasi analisisnya.

Kali ini penelitian dilanjutkan dengan mengoptimasi PRA menggunakan antena planar dengan patch berbentuk lingkaran dengan mengintegrasikan 24 kombinasi switch berupa shorting PIN di tepi patch dan celah melingkar yang diletakkan antara probe koaksial dan kombinasi switch yang digunakan sebagai metode penyepadan impedansi. Kemudian dilakukan optimasi pada antena tersebut tepatnya pada dimensi antena, kombinasi switch, serta dimensi celah melingkar untuk mengarahkan pola radiasi antena dan menahan frekuensi antena di 2,4 Ghz. Teknisnya, scripting HFSS dengan bahasa Visual Basic (VBScript) digunakan untuk mengintegrasikan AG pada Matlab dan Finite Element Method (FEM) pada Ansoft HFSS yang kemudian disebut sebagai AG/FEM Optimizer. 


\section{METODOLOGI}

Pada bagian ini akan dijelaskan mengenai struktur antena, prosedur umum Optimasi, blok diagram FEM/AG optimizer, pengaturan parameter pada Algoritma Genetika, dan mekanisme kemampuan pattern reconfigurable.

\subsection{Struktur Antena}

Antena yang diteliti adalah berbentuk planar dengan patch lingkaran. Pada patch tersebut dibuat celah melingkar berbentuk cincin dengan radius tertentu dan lebar celah tertentu. Dengan penambahan celah melingkar ini, posisi pencatuan bisa tetap berada di tengah patch sedangkan untuk keperluan penyepadan impedansi dilakukan dengan mengatur posisi celah/radius patch dalam dan lebar celah. Radius dalam patch-nya akan mempengaruhi frekuensi resonansi antena. J. Meixner (Meixner, 1956) memberikan gambaran mengenai karakteristik dan analisis antena patch lingkaran dengan celah melingkar. Kemudian 24 switch berupa shorting PIN diintegrasikan pada tepi patch. Adanya shorting pin merepresentasikan kondisi switch "ON" sedangkan tidak adanya shorting pin merepresentasikan kondisi switch "OFF". Antena dicetak pada bahan substrat Epoxy FR4. Dalam proses desain suatu antena, perubahan struktur fisik sedikit saja pada antena akan sangat mengubah karakteristik antena tersebut, terutama antena yang bekerja di frekuensi yang tinggi. Ditambah lagi kenyataan bahwa parameter antena satu dengan parameter yang lainnya bukanlah suatu parameter yang saling bebas melainkan sangat terkait satu dengan lainnya, artinya jika kita mengoptimasi pola pancar antenanya maka jelas parameter yang lain misalnya Return Loss-nya juga pasti akan berubah. Maka dari itu perlu dicari titik temu melalui proses optimasi (dalam penelitian ini menggunakan algoritma genetika) sehingga menghasilkan suatu desain antena yang secara teknis memenuhi spesifikasi yang dibutuhkan.

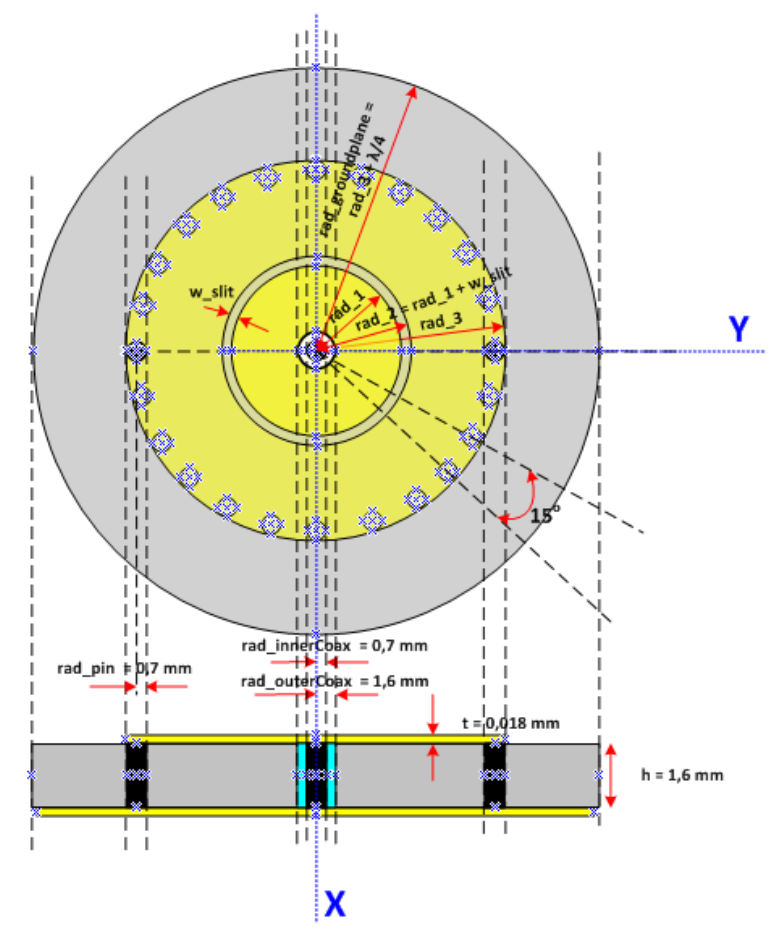

Gambar 2. Bagan PRA dengan Celah Melingkar 
Gambar 2 memperlihatkan struktur antena yang diteliti dan Tabel 1 menunjukkan nilai parameter awal dari antena.

Tabel 1. Parameter Awal PRA dengan Celah Melingkar

\begin{tabular}{|l|l|l|}
\hline Parameter & Simbol & Nilai \\
\hline Radius patch dalam & rad_1 & $35,7 \mathrm{~mm}$ \\
\hline Radius patch dalam ditambah lebar celah & rad_2 & $36,7 \mathrm{~mm}$ \\
\hline Radius patch total & rad_3 & $45 \mathrm{~mm}$ \\
\hline Lebar celah & W_slit & $1 \mathrm{~mm}$ \\
\hline Ketebalan strip conductor & t & $0,018 \mathrm{~mm}$ \\
\hline Ketebalan substrate & h & $1,6 \mathrm{~mm}$ \\
\hline Jari-jari dalam Coax & rad_innerCoax & $0,7 \mathrm{~mm}$ \\
\hline Jari-jari luar Coax & rad_outerCoax & $1,6 \mathrm{~mm}$ \\
\hline Jari-jari groundplane & rad_groundplane & $48,4 \mathrm{~mm}$ \\
\hline
\end{tabular}

Parameter antenna : radius patch dalam, lebar celah, dan kombinasi switch (shorting pin) akan dioptimasi.

\subsection{Prosedur Umum Optimasi}

Tujuan dari optimasi antena ini adalah mencari kombinasi switch yang akan menghasilkan pola radiasi yang sesuai dengan spesifikasi/target. Adapun target pola radiasi antena yang dimaksud adalah $45^{\circ}$ arah elevasi seperti ditunjukkan pada Gambar 3. Pemilihan arah target ini didasarkan pada dua hal, pertama : batasan akan karakteristik antena berbentuk planar dengan sebuah groundplane yang hanya bisa dimodifikasi pola pancarnya antara $0^{\circ}$ sampai $90^{\circ}$ arah elevasi. Kedua : PRA yang dirancang ini menitikberatkan perubahan pola radiasi di bidang azimuth dengan memanfaatkan struktur antena yang simetris, sehingga pada arah azimuth, target pola radiasi tidak perlu ditetapkan secara spesifik, karena pada akhirnya nanti antena ini bisa men-sweep seluruh arah azimuth dari $0^{\circ}$ hingga $360^{\circ}$. Adapun syarat/batasan dari optimasi ini adalah tetap terpenuhinya matching impedansi di terminal antena pada frekuensi kerja 2,4 Ghz.

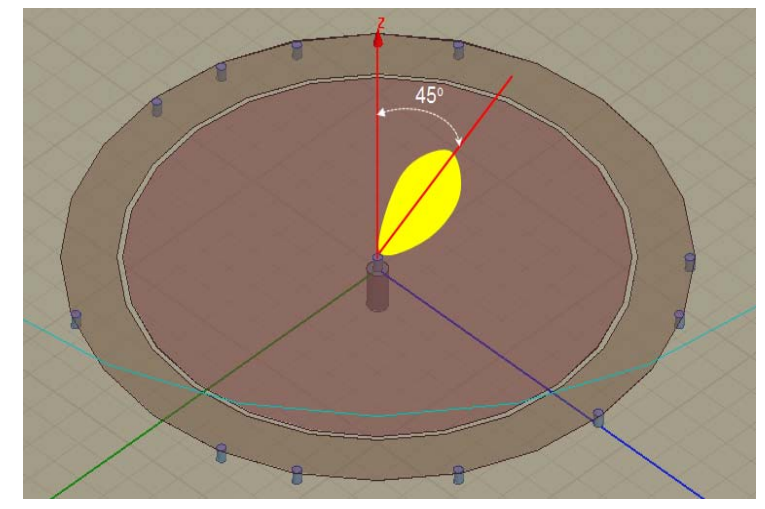

\section{Gambar 3 Ilustrasi Pola Pancar Antena Target}

Untuk mencapai target tersebut, variabel-variabel seperti kombinasi switch, lebar celah melingkar, dan radius patch dalam akan dioptimasi.

Pada saat hasil optimasi mencapai optimum, didapat suatu desain antena yang bekerja pada frekuensi 2,4 Ghz dan memiliki arah pola pancar $45^{\circ}$ arah elevasi dengan arah azimuth sembarang. 
Prinsip kerja AG pada kasus optimasi kombinasi switch antena ini bisa dijelaskan sebagai berikut :

1. Awalnya ambil sekumpulan individu (populasi), yang kita sebut generasi satu,

2. Tiap individu diwakili dengan bit-bit biner (kromosom) sejumlah switch yang digunakan yaitu 24 bit, ditambah bit-bit lain yang digunakan untuk kode variabel lainnya. Dalam hal ini, variabel radius patch dan lebar celah masing-masing dikodekan dengan 10 bit, sehingga totalnya ada 44 bit.

3. Bit ' 0 ' dan bit ' 1 ' pada parameter kombinasi switch merepresentasikan kondisi switch 'Off' (tiadanya shorting pin) dan switch "On" (adanya shorting pin). Gambar 4 mengilustrasi pengkodean variabel antena pada struktur antena.

4. Lalu setiap kromosom dicek fungsi fitnesnya,

5. Apabila pada generasi pertama tersebut sudah didapat kriteria yang diharapkan, maka proses selesai. Tetapi jika belum ada individu yang memenuhi kriteria, maka individu dengan nilai fitness yang tertinggi akan dipilih untuk dijadikan orang tua (parent).

6. Langkah selanjutnya dilakukan penggabungan kromosom (cross over) pada 2 buah parent dengan dilakukan sedikit pemodifikasian kromosom (mutasi), kemudian generasi baru dibentuk, kita sebut generasi kedua.

Generasi yang kedua ini kemudian dievaluasi lagi. Proses ini berulang sampai kriteria terpenuhi atau sampai seluruh generasi selesai dievaluasi.

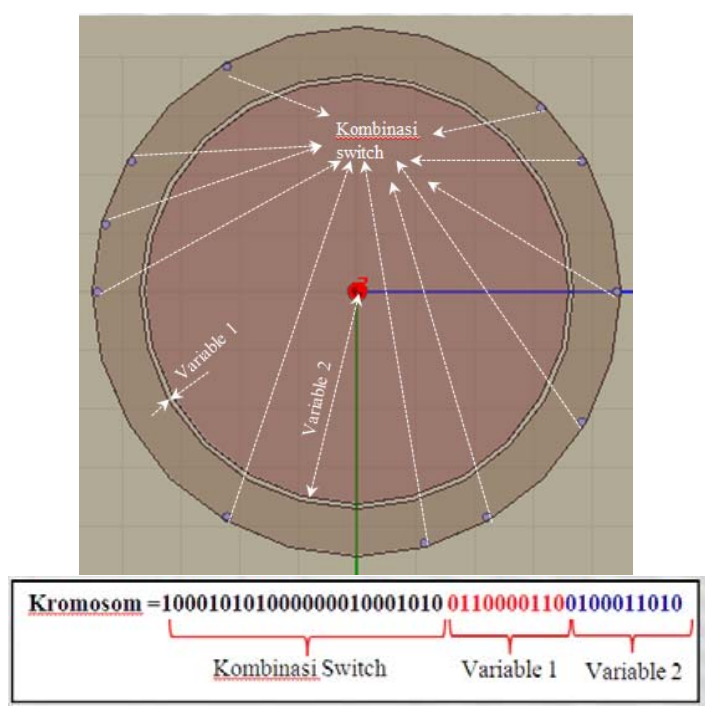

\section{Gambar 4. Ilustrasi Kromosom (AG) pada Struktur Antena}

\subsection{Blok Diagram FEM/AG Optimizer}

FEM/AG Optimizer terdiri dari tiga buah proses utama yaitu :

1. Initiation

Proses inisiasi adalah penerjemahan permasalahan utama yang sedang dioptimasi kelingkungan AG. Termasuk didalamnya proses pembangkitan populasi dan proses seleksi.

2. Reproduction Cicle

Pada bagian ini proses pencarian cikal bakal generasi baru dilakukan seperti parent selection, crossover, dan mutasi.

3. Population Generation

Bagian ini adalah bagian terakhir dimana semua populasi pada suatu generasi digantikan dengan generasi baru dan terjadi kembali proses seleksi. 
Blok Diagram AG/FEM Optimizer bisa dilihat pada Gambar 5.

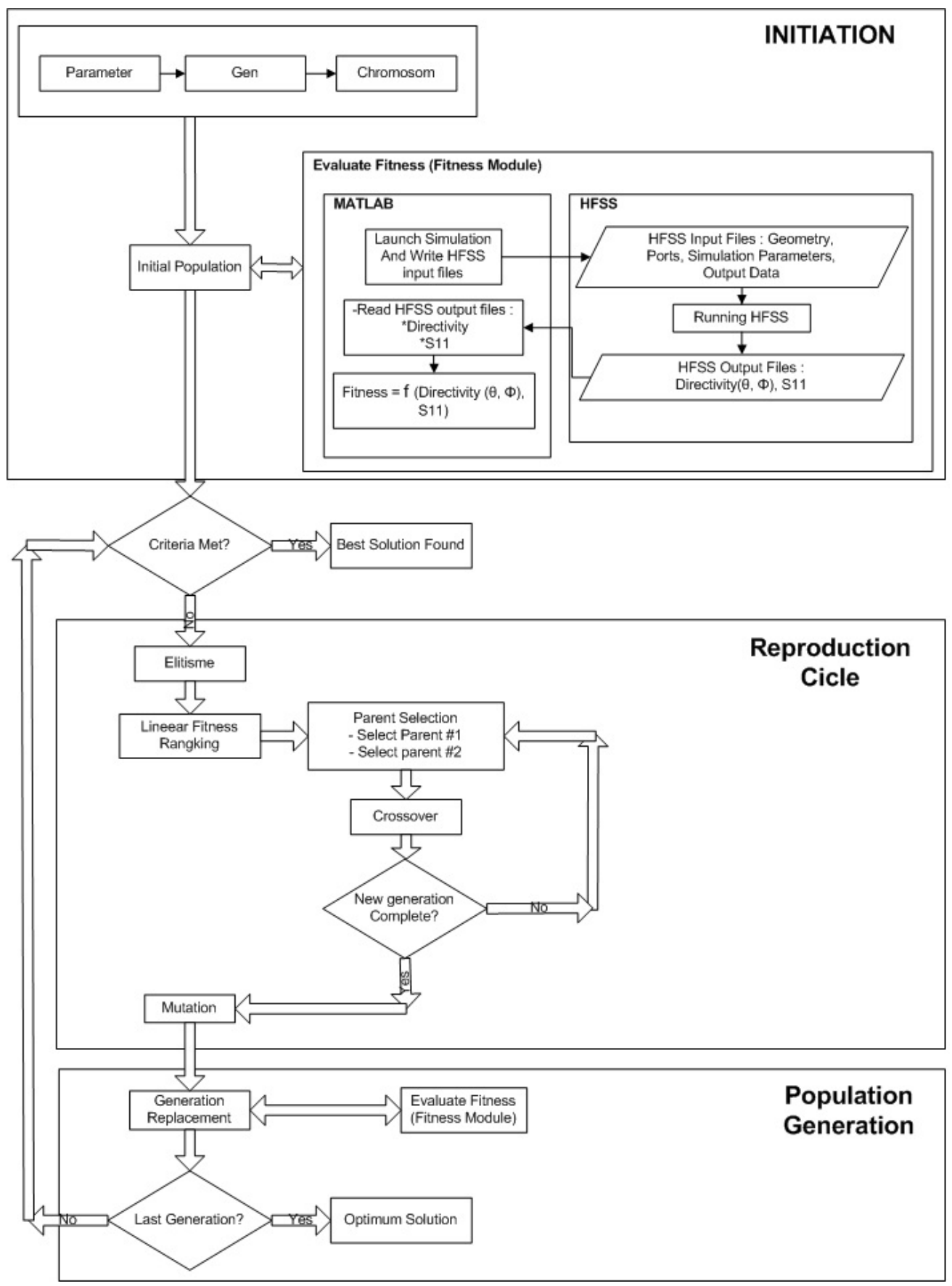

Gambar 5. Blok Diagram FEM/AG Optimizer

\subsection{Pengaturan parameter AG}

Ukuran populasi, probabilitas crossover, dan probabilitas mutasi merupakan parameter AG yang paling mempengaruhi hasil optimasi. Ukuran populasi tidak boleh terlalu sedikit karena akan membuat rendahnya variasi kromosom tiap generasi yang menyebabkan konvergensi 
dini, tapi ukuran populasi juga tidak boleh terlalu besar karena akan membebani prosesor saat proses komputasi. Pada penelitian ini penulis menggunakan ukuran populasi 32 dengan pertimbangan agar waktu komputasi tidak terlalu lama.

Tabel 2 menunjukkan ringkasan pengaturan parameter AG yang digunakan pada penelitian ini.

Tabel 2. Pengaturan Parameter AG pada PRA

\begin{tabular}{|l|l|}
\hline \multicolumn{1}{|c|}{ Istilah } & \multicolumn{1}{c|}{ Keterangan dan Setup } \\
\hline Populasi & Ukuran Populasi $=32$ \\
\hline Kromosom & Satu kromosom $=44$ bit \\
\hline Gen & gen 1 : Kombinasi Switch (24 bit), gen2 : Rad_1 (24 bit), gen 3 : W_slit (10 bit) \\
\hline Orang Tua & - \\
\hline Pindah Silang & One-point Crossover dengan Probabilitas pindah silang $=0,875$ \\
\hline Mutasi & $\begin{array}{l}\text { Seluruh bit dalam kromosom punya kemungkinan terjadi mutasi dengan probabilitas } \\
\text { mutasi }=0,01\end{array}$ \\
\hline Prosedur Seleksi & Roulette Wheel Selection \\
\hline Fungsi Evaluasi & Fitness Function $=4 \times$ Directivity $(\theta, \phi)+\left|S_{11(d B)}(f)\right|$ \\
\hline Generasi & Maksimum Generasi $=10$ \\
\hline
\end{tabular}

\subsection{Mekanisme Kemampuan Pattern Reconfigurable}

Hasil optimasi pada bagian subbab sebelumnya belum merupakan antena yang memiliki kemampuan pattern reconfigurable, tetapi sangat potensial untuk menjadi kandidat sebagai PRA.
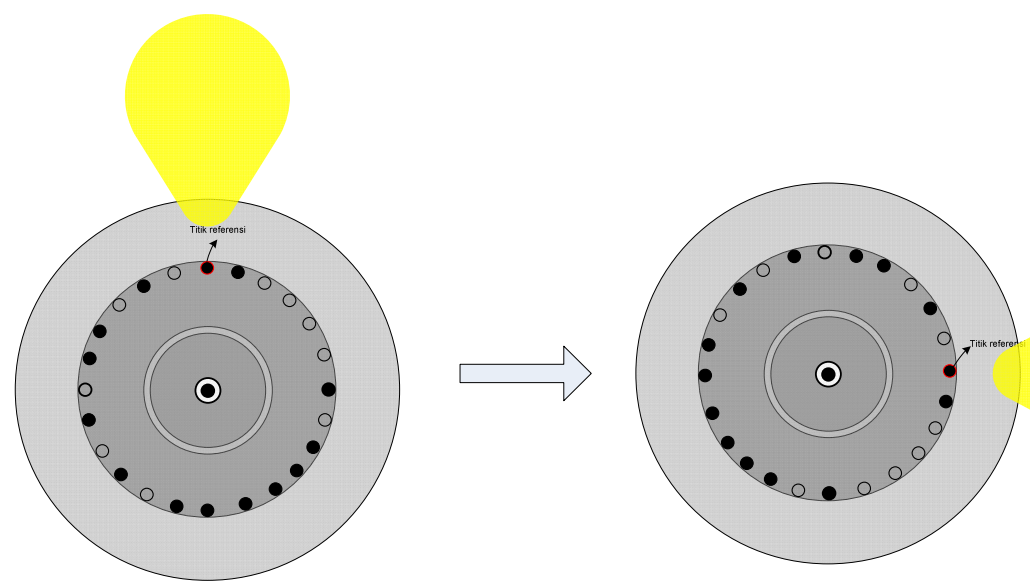

Gambar 6. Ilustrasi Mekanisme Pattern Reconfigurable

Agar antena ini memiliki kemampuan pattern reconfigurable, maka mekanisme berikut perlu dilakukan yaitu dengan mengubah kombinasi switch (state) dengan cara memutar susunan kombinasi switch tersebut sehingga pola radiasi antena arah azimuth akan berputar juga sejauh maksimal $360^{\circ}$ dengan derajat reconfigurability tiap state sebesar $15^{\circ}$. Hal ini memungkinkan karena struktur antena yang simetris. Ilustrasi mekanisme kemampuan pattern reconfigurable bisa dilihat pada Gambar 6. 


\section{HASIL OPTIMASI DAN PENGUKURAN}

Simulasi menggunakan AG/FEM Optimizer menunjukkan hasil yang optimum tercapai saat fungsi fitness bernilai 37,97 pada iterasi terakhir (generasi 10) dan ditunjukkan pada Gambar 7 dengan nilai variabel optimum ditunjukkan pada Tabel 3.

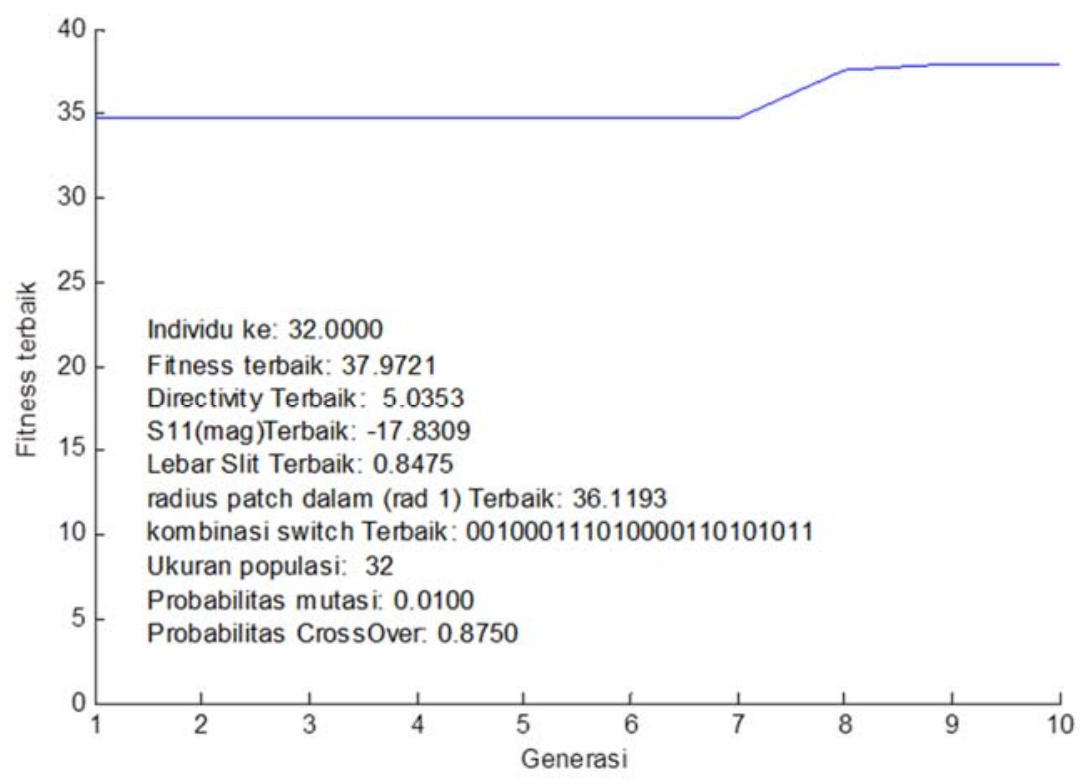

\section{Gambar 7. Grafik Fungsi Fitness Optimasi PRA dengan Celah Melingkar}

\section{Tabel 3. Variabel Optimum pada PRA dengan Celah Melingkar}

\begin{tabular}{|l|l|}
\hline \multicolumn{1}{|c|}{ Variabel } & \multicolumn{1}{c|}{ Nilai Optimum } \\
\hline Rad_1 & 36.1192570869990 \\
\hline w_slit & 0.847507331378299 \\
\hline Kombinasi Switch & 001000111010000110101011 \\
\hline
\end{tabular}

Hasil simulasi karakteristik antena menggunakan variabel optimum ditunjukkan pada Gambar 8. Terlihat bahwa beam utama antena sudah mengarah pada sudut elevasi $45^{\circ}$, dan frekuensi kerjanya pada 2,4 Ghz dengan Return Loss (RL) sebesar $-22,5 \mathrm{~dB}$, direktivitas antena sebesar 5,03 atau $7 \mathrm{~dB}$ serta bandwidth 98,5 Mhz (4,13\%). Nilai-nilai tersebut sudah memenuhi spesifikasi awal antena.

Hasil pola radiasi antena dari state-state ganjil bisa dilihat pada tabel Tabel 4 dan perubahan $R L$-nya bisa diamati pada Gambar 10 dan dapat disimpulkan bahwa perubahan state satu ke state lainnya pada antena dapat merubah pola radiasi antena dengan "tanpa mengubah" frekuensi kerja dan karakteristik pantulannya atau Return Loss-nya. 


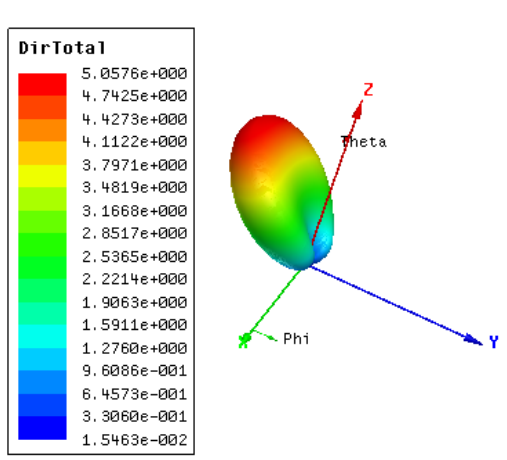

(a)

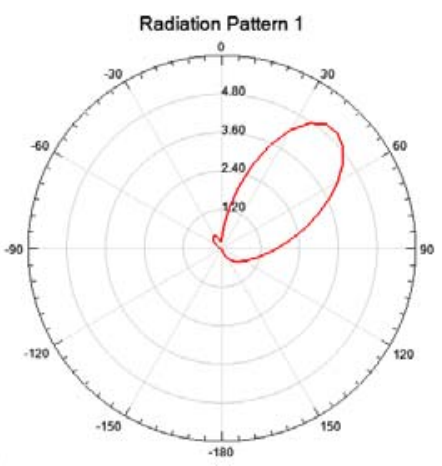

(b)

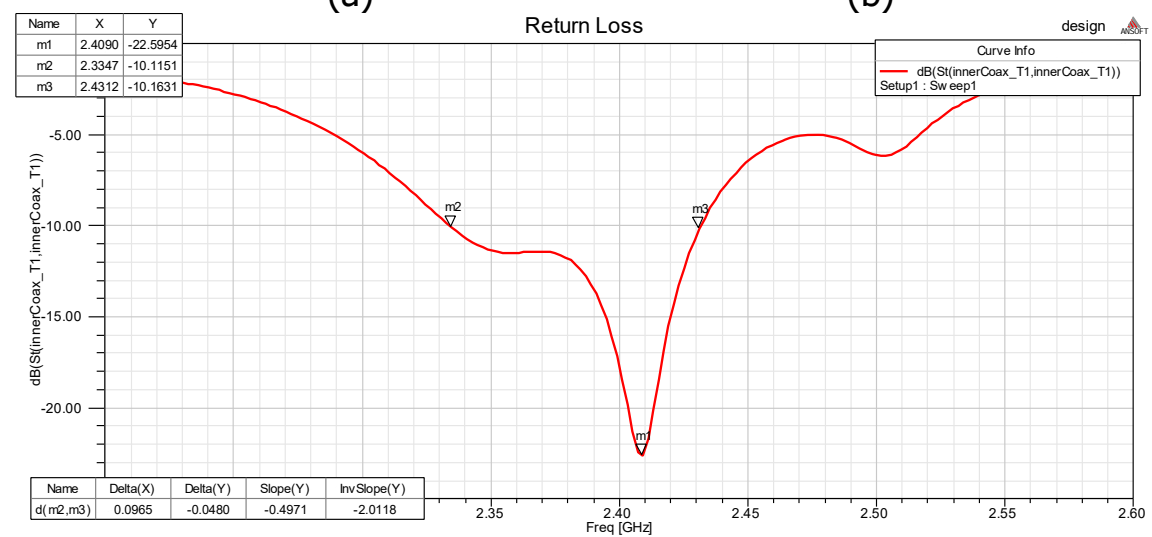

(c)

Gambar 8. Karakteristik PRA dengan Celah Melingkar pada Variabel Optimum : (a) Pola Pancar 3D, (b) Pola Pancar 2D, (c) RL

Dari Gambar 10 juga bisa disimpulkan bahwa perubahan atau pergeseran frekuensi kerja dan nilai Return Loss tidak terlalu signifikan dan yang paling utama adalah masih memenuhi dari spesifikasi antena.

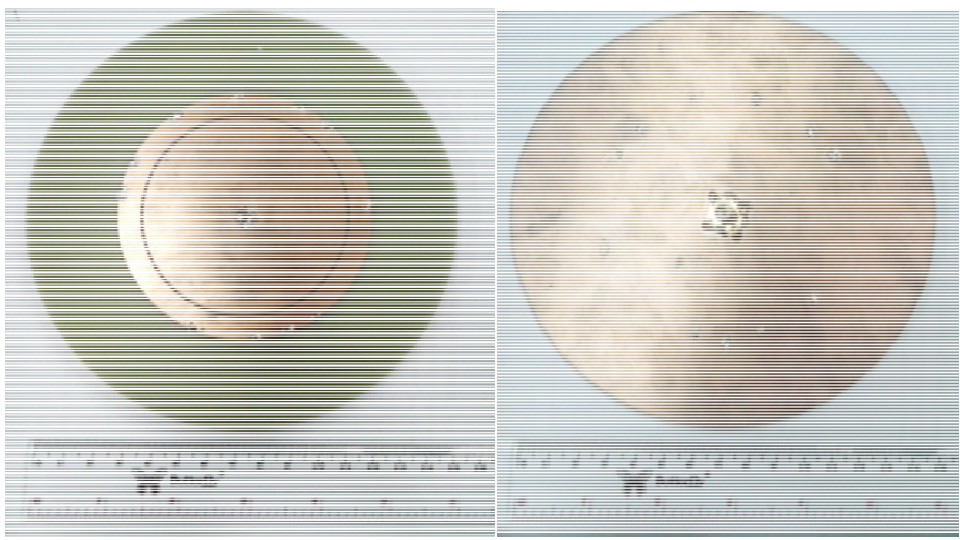

(a) (b)

Gambar 9. Hasil Fabrikasi PRA dengan Celah Melingkar, (a) Bagian Depan, (b) Bagian Belakang 
Hasil pembuatan antena bisa dilihat pada Gambar 9 dengan radius dalam patch sebesar $36.1193 \mathrm{~mm}$, radius luar patch $45 \mathrm{~mm}$, lebar celah $0.8475 \mathrm{~mm}$, radius groundplane 76.25 $\mathrm{mm}$, ketebalan substrat 1,6 mm, serta kombinasi switch 001000111010000110101011.

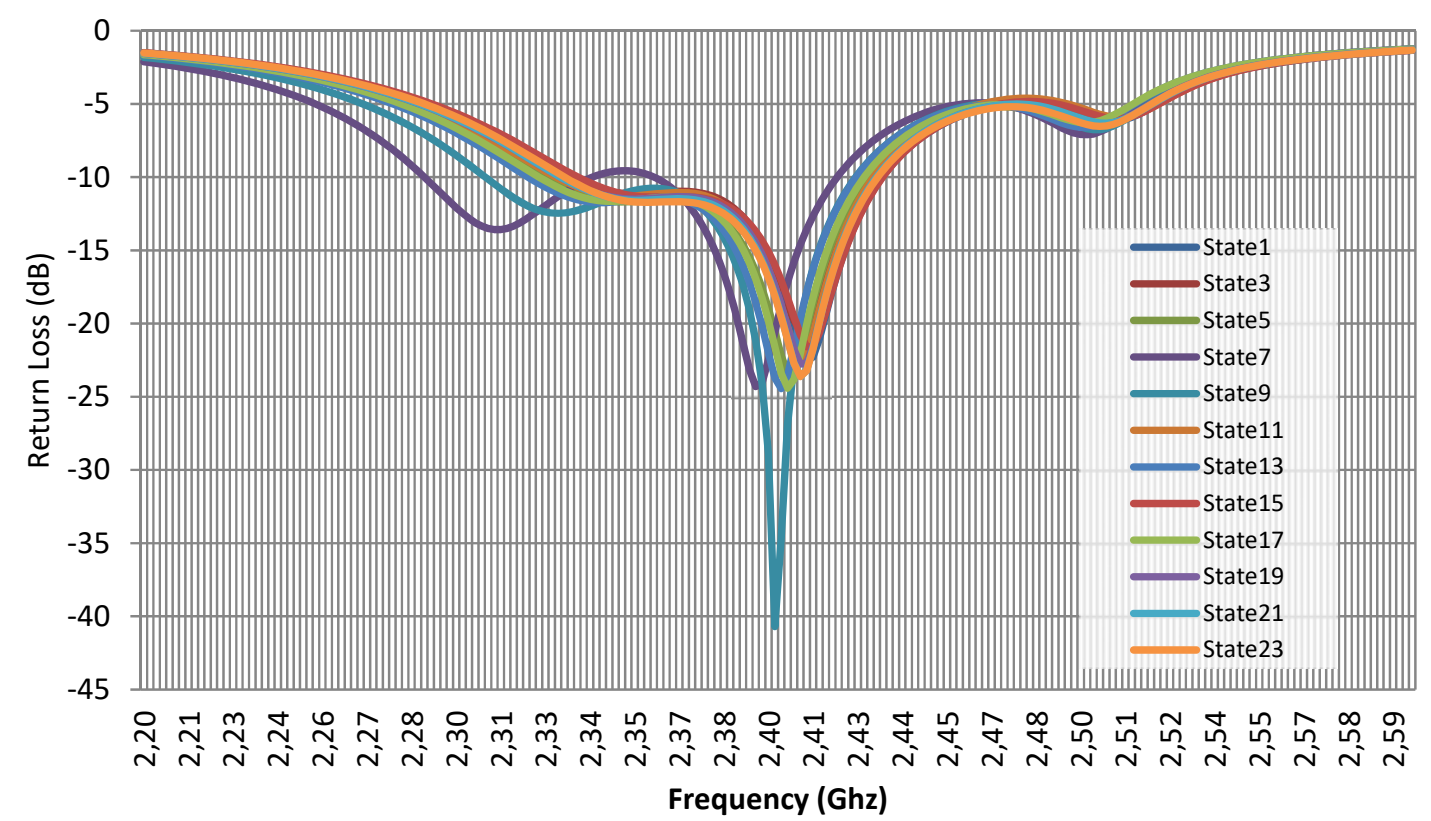

Gambar 10. RL pada PRA dengan Celah Melingkar pada 12 State Ganjil

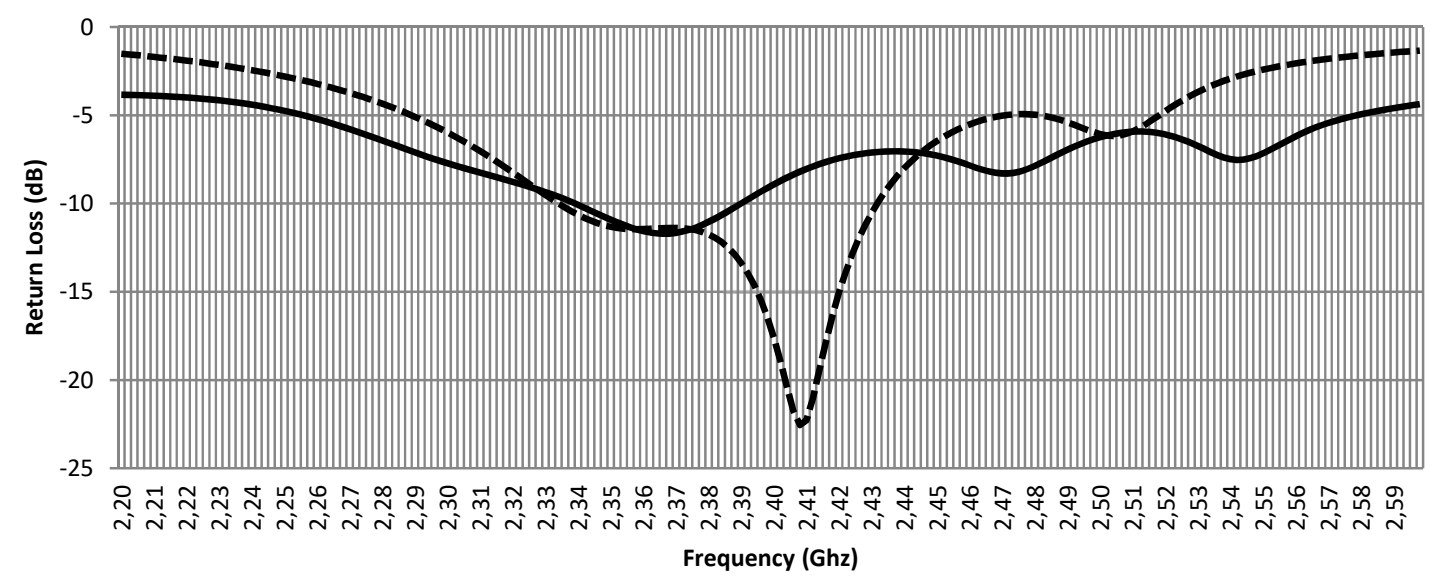

- Simulasi Pengukuran

Gambar 11. Perbandingan RL Semulasi dan Pengukuran pada PRA dengan Celah Melingkar 


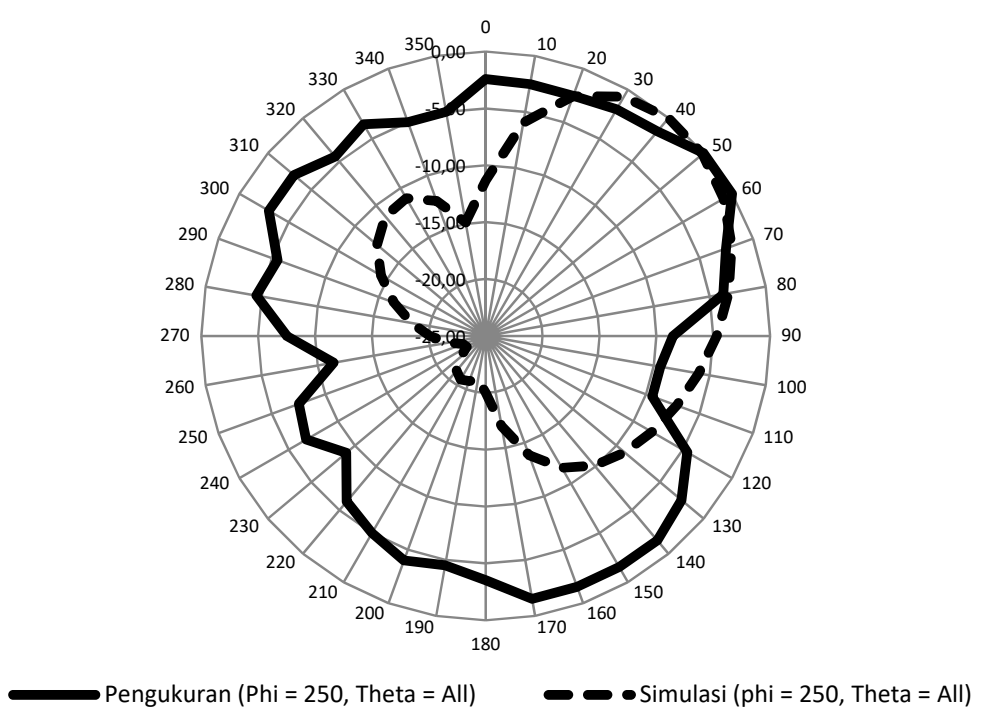

\section{Gambar 12. Perbandingan Pola Pancar PRA dengan Celah Melingkar antara Simulasi dan Pengukuran}

Gambar 11 dan Gambar 12 masing-masing menunjukkan grafik perbandingan nilai Return Loss dan perbandingan pola radiasi antara hasil simulasi dan pengukuran. Dari hasil perbandingan ini terlihat memang ada perbedaan antara hasil simulasi dan pengukuran. Meskipun perbedaan ini tidak terlalu jauh, tetapi perlu ketelitian tinggi pada saat proses fabrikasi dan penyolderan agar hasil pengukuran tidak melenceng jauh dari hasil simulasi dan spesifikasi awal. Selain itu proses pengukuran juga perlu dibuat seideal mungkin agar hasil pengukuran menjadi akurat.

Tabel 4. Pola Pancar PRA dengan Celah Melingkar pada 12 State Ganjil

\begin{tabular}{|c|c|c|c|}
\hline $\begin{array}{l}=0 \ldots \\
= \\
= \\
\text { State 1 } \\
001000111010000110101011\end{array}$ & $\begin{array}{l}Q_{1} \\
\text { State } 3 \\
110010001110100001101010\end{array}$ & 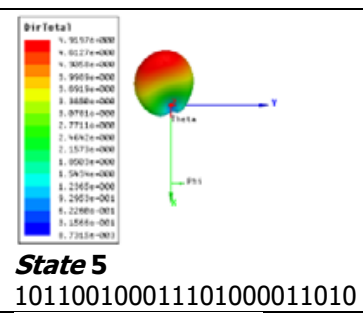 & $\begin{array}{l}=0 \\
\text { State } 7 \\
101011001000111010000110\end{array}$ \\
\hline 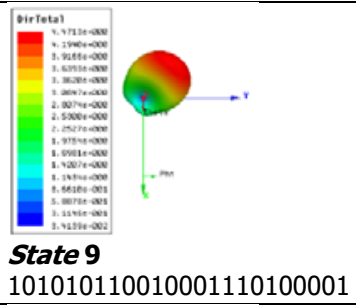 & 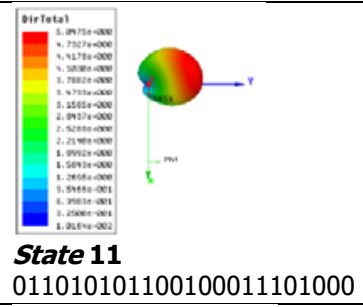 & 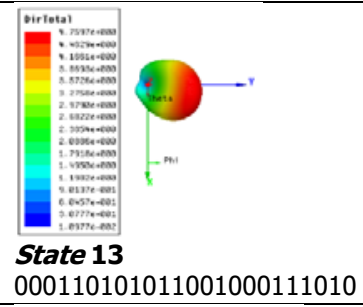 & 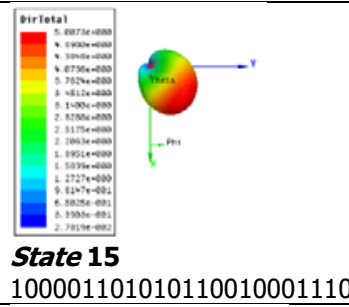 \\
\hline 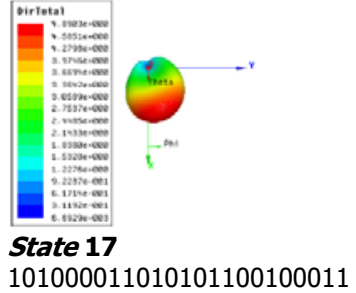 & 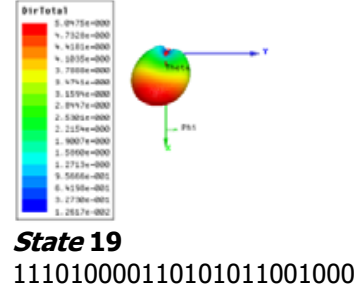 & 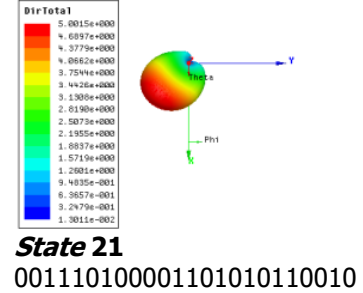 & 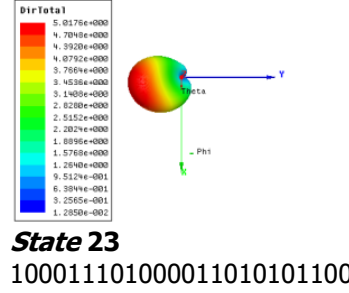 \\
\hline
\end{tabular}




\section{KESIMPULAN}

Suatu teknik optimasi yang menggabungkan algoritma genetika dan Finite Element Method pada antena planar dengan patch berbentuk lingkaran yang diintegrasikan shorting pin pada pinggir patch serta celah melingkar di antara titik pencatuan dan shorting pin telah dipaparkan. Metode ini telah berhasil mendapatkan suatu desain PRA pada frekuensi 2,4 Ghz dengan 24 pola pancar yang bisa di-switch ke seluruh bidang azimuth arah pancar elevasi sebesar $45^{\circ}$. Untuk penelitian kedepan, implementasi $R F$ Switch pada PRA ini perlu dilakukan.

\section{DAFTAR RUJUKAN}

Farran, M., Al-Hussein, M., Kabalan, K., Capobianco, A.-D., \& Boscolo, S. (2019). Electronically reconfigurable parasitic antenna array for pattern selectivity. The Journal of Engineering, 1-5.

Gulati, M., Siddhartha, S., Vedi, Y., \& Susila, M. (2018). Genetic-Algorithm Based Planar Antenna Design. 2018 International Conference on Wireless Communications, Signal Processing and Networking (WiSPNET) (pp. 1-2).

Guo, Y. J., Qin, P.-Y., Chen, S.-L., Lin, W., \& Ziolkowski, R. W. (2018). Advances in Reconfigurable Antenna Systems Facilitated by Innovative Technologies. IEEE Access , 6, $5780-5794$.

Li, Y., Hong, W., Li, M., \& Lu, G. (2018). Unequally Spaced linear antenna arrays Synthesis Based on Genetic Algorithm. 2018 International Workshop on Antenna Technology (iWAT) (pp. 1-4).

Meixner, J. (1956, July). The radiation pattern and induced current in a circular antenna with an annular slit. IRE Transactions on Antennas and Propagation, 4(3), 408-411.

Nurmantris, D. A., Wijanto, H., \& Nugroho, B. S. (2014). A pattern reconfigurable of circular short-circuited patch antenna based on Genetic Algorithm. 2014 2nd International Conference on Information and Communication Technology (ICoICT) (pp. 351-355).

Nurmantris, D. A., Wijanto, H., \& Nugroho, B. S. (2015). Pattern Reconfigurable Patch Antenna menggunakan Edge Shorting Pin dan Symmetrical Control Pin. ELKOMIKA: Jurnal Teknik Energi Elektrik, Teknik Telekomunikasi, \& Teknik Elektronika , 3(2), 177-190.

Rezaeieh, S. A., \& Abbosh, A. M. (2019, April). Pattern-Reconfigurable Magnetoelectric Antenna Utilizing Asymmetrical Dipole Arms. IEEE Antennas and Wireless Propagation Letters, 18(4), 688 - 692. 
Smith, J. S., \& Baginski, M. E. (2019, May). Thin-Wire Antenna Design Using a Novel Branching Scheme and Genetic Algorithm Optimization. IEEE Transactions on Antennas and Propagation, 67(5), 2934 - 2941.

Tang, M.-C., Duan, Y., Wu, Z., Chen, X., \& Li, M. (2018, March). Pattern Reconfigurable, Vertically Polarized, Low-Profile, Compact, Near-Field Resonant Parasitic Antenna. IEEE Transactions on Antennas and Propagation, 67(3), 1467 - 1475.

Yang, Y., \& Zhu, X. (2018, February). A Wideband Reconfigurable Antenna With $360^{\circ}$ Beam Steering for 802.11ac WLAN Applications. IEEE Transactions on Antennas and Propagation, 66(2), 600-608.

Zeghdoud, A., Derbal, M. C., \& Nedil, M. (2018). Optimization of a Dual-band Microstrip antenna Array using Genetic Algorithms. 2018 IEEE International Symposium on Antennas and Propagation \& USNC/URSI National Radio Science Meeting (pp. 10051006).

Zhang, Z., Yang, S., Liu, M., Deng, S., \& L, L. (2019). Design of an UWB Microstrip Antenna With DGS Based on Genetic Algorithm. 2019 21st International Conference on Advanced Communication Technology (ICACT) (pp. 251 - 255). 